\title{
Evaluation of Causes of Claims on Construction Projects of Southern Nation Nationality and People Region (SNNPR), Ethiopia
}

\author{
Ashenafi Reta ${ }^{1}$ \\ ${ }^{1}$ Lecturer, \\ Civil Engineering Department, \\ Wolaita Sodo University, Ethiopia
}

\author{
Matusala Bassa ${ }^{2}$ \\ ${ }^{2}$ Lecturer, \\ Civil Engineering Department, \\ Wolaita Sodo University, Ethiopia
}

\author{
Ashebir Alyew ${ }^{3}$ \\ ${ }^{3}$ Lecturer, \\ Civil Engineering Department, \\ Wolaita Sodo University, Ethiopia
}

\begin{abstract}
Construction projects involve a number of parties (Owners, Contractors, Consultants, Local authorities) who arise claims that have occurred frequently and significantly. Construction Claims are a global phenomenon since one of the most important factor in the Construction industry is Claim. Claims can be in the form of demands of time extension or cost compensation or both requested mostly by contractors. The major issues in claims and disputes are identification of issues and the party responsible for the claims, and ascertaining the time and cost impact of the claim. A global claim is one where the claimant has identified the terms of the contract on which he/she relies, the facts constituting the breaches of the contract terms. For the purpose of this paper, research is defined as a methodological search or inquiry to ascertain new facts or collect old facts by scientific study for the purpose of developing existing theory or its application in a real problem. Southern Ethiopia construction projects, as of Ethiopian public construction project, have three main traditional form of participants, the employer/client/owner, the consultant and the contractor. The objective of the study is assessing Causes of construction claims. And the scope of the study focuses on assessing the causes of claim on Construction projects southern part of Ethiopia in SNNPR. A survey in the form of structured questionnairas were prepared for the Client, Contractor, Consultant and other participant professionals of construction projects. Relative importance index was used here to determine client (client's representative) and contractor perceptions about the most important factors causing claim. Analysis and processing of research involves examining, categorizing, tabulating, evidences to address the initial problem statement. The research instruments were designed properly to ease examining, categorizing and tabulating the research responses. The study drawn conclusion about the Causes of claim depend on the result of analyzed data.
\end{abstract}

Keywords: Project management; construction; claim; Southern Nation Nationality People

\section{INTRODUCTION}

Claim is the most challenging matter in construction project. It is the main source of problem in construction project. Construction projects involve a number of parties who arise claims that have occurred frequently. Hence this expose stakeholders specially the owner and the contractor too many problems. In the construction industry the word 'claim' is commonly used to describe any application by the contractor for payment which arises other than under the ordinary contract payment provisions. In the context of construction industry, claims means, a demand by a contractor for extension of time or for an extra payment of an item of work carried out by him on behalf of the employer for which a readily identifiable amount cannot be ascertained under the term of contract [1] . In SNNPR there is many construction projects those accounted with claims between the stakeholders of the projects. To complete the projects without dispute, early understanding of the cause of claim is necessary. Therefore, this fact demands for a closer evaluating on the cause claims in building construction projects in SNNPR. In doing so, the research will generate some insights into the complexity of the construction project work process. Generally, this study helps to minimize the cost that may incurred when solving the happened claims in the construction industry. So, it has economic advantages for the construction industry as a whole.

\section{CLASSIFICATION OF CLAIM}

There are different types and classification of claim as described by different scholars based on legal basis, characteristics of claim, related parties and rights claim. This in general summarized as Extra item or variation claim, delay in completion time claim, change of work order claim, cost claim, price acceleration claim, Different site condition claim, contractual claim, common law claim, ex-gratia claim, claim related with weather condition, claim in tort and quantum merit claim.

\section{CAUSES OF CLAIM}

The study in china outlines the causes of contractors' claims as: external risk (sociopolitical risks, economic risks, and natural hazards), clients' organizational behavior (untimely payment, change orders, and inefficient processing), and project definition in contract (unclear scope of works, and 
unclear technical specification) [2]. The result of study in Nigeria revealed that changes or modifications of scope that increase consequential cost beyond initial cost. Variation and late confirmation of variations, design professionals, failure to remain within the client budget and design objectives, discrepancies/ambiguities in the context documents, late information delivery, over measurement and under measurement of work by consultants to work in progress, design and specification oversight, error or omissions resulting from uncoordinated civil structural, architectural as the most important underlying causes [3]. Contractors claim such as common law claim (arise from causes which are outside the express terms of a contract.), ex gratia claim (These have no legal basis but are claims, which the contractor considers the Employer has a moral duty to meet), contractual claim (arise from express terms of a contract and form by far the most frequent kind of claim.) may relate to any or all of the following such as Fluctuations, variations, extension of time, loss and/or expense due to matters affecting regular progress of works [4]. According to the study conducted in Oman owners are the main sources of claim followed by consultant and contractor with equal percent [5]. The study conducted in Ethiopia revealed the causes of claim as claims due to the late handing over of the site, financial claim due to variation of work and time extension claim due to design issues [6]. The study in Niger state Nigeria outlines the causes of construction claim as Unrealistic time targets, Poor communication, Incomplete tender information, Slow client response (decisions), Inadequate design information, Inaccurate design information, Effects of high inflation in the construction sector, Inadequate site investigations, Inadequate contract administration, Uncontrollable external events, Increased complexity of building projects, Increase in government regulations, Unclear risk allocation, Increased competition due to decrease in the number of projects in the area, A decrease in profits, Withdrawal of governmental support hitherto extended to the contractor [7]. In the FIDIC form of contract, the principal bases of claim, which may be submitted, are among others the following: 1) Costs associated with the encountering of physical obstructions and conditions which would not have been foreseeable by an experienced Contractor (Clause 12.2), 2) Errors in setting out which are based on incorrect written data Supplied by the Engineer (Clause 17.1), 3) Loss or damage due to employer's risks (Clause 20.3), 4) Indemnities that the employer has contractually undertaken to assume (Clause 22.3), 5) Fossils or discovery of things of geological or archaeological interest (Clause 27.1), 6) Delays caused by other interfacing contractors (Clause 31.2), 7) Uncovering work that has already been completed (Clause 38.2), 8) Suspension of the work ordered by the Engineer (Clause 40.2), 9) Late Possession of the site, which is as a result of a failure of the employer to give the required handover (Clause 42.2), 10) Remedying defects not the responsibility of the Contractor (Clause 49.3) , 11) Searching for defects which are not the fault of the Contractor (Clause 50.1), 12) Valuation of variations which may include alternations, additions and/or omissions (Clause 52), 13) Provisional sums pending a proper valuation of the variation under Clause 52 above
(Clause 58), 14) Special Risks which very often include war, hostilities, contamination, riots and other such risks (Clause 65 ) and15) Fluctuations of labor costs (if provided for) and subsequent legislation that adversely effects the project (Clause 70) [8]. The study conducted in India indicate the most frequent causes of claim includes payment related claim, change related claim, delay claim, extra work claim, contractual work claim, different in pricing and measuring claim, different site condition claim, acceleration claim, damage claim and contract termination claim [9]. The study conducted in Ethiopia at Yeka sub city indicated the top three main causes of claim as 1) client related causes of claim (Payment delays for contractor ; Inadequate construction details, Sequence of work directed by owner) 2) contractor related causes of claim (Variation work, Non adherence to site instructions, Project coordination problems) 3) contract document related causes(Leverage for enforcement of schedule specification, Power of individual party vaguely specified, Permitting responsibilities Vague ) [10]. Generally the followings are causes of claim identified by different scholars such as Extension of time, variations, late supply of working drawing, late supply of materials, poor quality of materials, increasing cost of materials, late payment, late site handover, late start of work, delay in completion of work, cost due to idle equipment and labour, error in design, error in bid documents, clients lack of construction knowledge, poor technical capability of contractor, financial problems of contractors, poor management of construction site, lack of site investigation, poor bidding process, discrepancy between contract documents, Accidents at site, weather condition and unforeseen ground condition.

\section{EFFECTS OF CLAIM}

According to the study conducted in Oman the most effect in construction project is extension of time, work suspension and payment delay [5]. The study made in Ethiopia outlines the effects of claim as financial effect of claims, effect on Project Completion Time and effect on project execution itself [6].

\section{REQUIREMENTS FOR CLAIM}

For the claim to be successful, it has to fulfill valid requirements [11] such as:-

$\checkmark$ Substantive requirements (supporting or giving justification for the claim by specifically citing the provisions of Applicable Law and/or contract documents.

$\checkmark$ Procedural Requirements (serving of the required prior written notice to the designated party under the contract.) The non-observance of the procedural requirement may result whole or partial loss of the substantive claim.

$\checkmark$ Proof Requirements (submitting the relevant documentation which support the claims under consideration.) 


\section{PROCESS OF CLAIM}

The claims process generally classified in to the following three phases [12] such as:-

$\checkmark$ Claim Submittal (This is a process by which the claimant is obliged to claim within a reasonable period of time (28-30 days in most contracts) followed by the claimant's preparation for all substantial documents \& legal aspects supporting its entitlements for an official submittal.) It has three sub process 1) Claim Notification, 2) Claim Preparation \& 3) Claim Submittal.

$\checkmark$ Claim Processing (has three sub classification 1) Claim Handling; 2) Dispute Resolution; and 3) Claim Approval)

$\checkmark$ Claim Enforcement ( further subdivided in to two 1) claim enforcement and 2) claim closure)

\section{RESEARCH OBJECTIVES}

This study identifies the causes of claim in the construction projects of SNNPR.

The objectives are:-

1. To analyze construction claim in SNNPR construction projects.

2. Evaluating the causes of claim in SNNPR construction projects.

\section{METHODOLOGY}

In order to Determine and analyse the causes of claim in construction projects of SNNPR, a wide range of personnel involved in construction projects of SNNPR were targeted. Personnel were randomly selected from project managers, consultants, contractors, client's representatives and construction managers. A questionnaire was carefully designed from previous preliminary investigations conducted in construction projects in SNNPR. It was organised in the form of a priority scaling ( $1=$ very low, 2=low, 3=medium, 4=high, and 5=very high). The questionnaire was directed towards three groups in both public and private organisations: owners of the Building projects, consulting offices, and contractors working in the construction works. The questionnaire was distributed to a random sample of clients, consultants and contractors. The sample selected for each of the three groups is described below as:

$>$ Clients encompassing the government agency responsible for the projects, private organisations, and individual owners.

$>$ Consultants working in the construction projects of southern nation.

Contractors who are involved in the construction projects of southern nation.

Respondents were from public and private agencies that sponsor construction projects, and the contracting and consulting organisations that work for them

\section{Data Analysis}

The Relative Important Index (RII) method was adopted for similar studies to determine the relative importance of various factors [13]. This method is applied to this study to identify the Relative importance of various causes of claim based on responses from contractors, Employers and consultants.

$$
\mathrm{RII}=\left(\frac{\sum(W)}{A * N}\right)
$$

where: $\mathrm{W}=$ the weight given to each factor by the respondents

$\mathrm{A}=$ the highest weight $=5$

$\mathrm{N}=$ the total number of respondents.

The RII is used to rank the groups of questionnaire by calculating the average of relative importance index of all factors in the group.

\section{RESULT ANALYSIS AND DISCUSION}

Table 1: RII and Rank of top 5 Client Related Causes of Claim (Contactors` perspective)

\begin{tabular}{|l|c|c|}
\hline \multicolumn{1}{|c|}{ Causes } & RII & Rank \\
\hline Delay in payment (cash flow problem) & 0.83 & 1 \\
\hline Change of client`s requirement & 0.79 & 2 \\
\hline Finance limitation to fund the project & 0.61 & 3 \\
\hline Oral change order (failure to give written instruction) & 0.58 & 4 \\
\hline Lack of awareness about construction & 0.57 & 5 \\
\hline
\end{tabular}




\section{Top 5 Client related causes of claim}

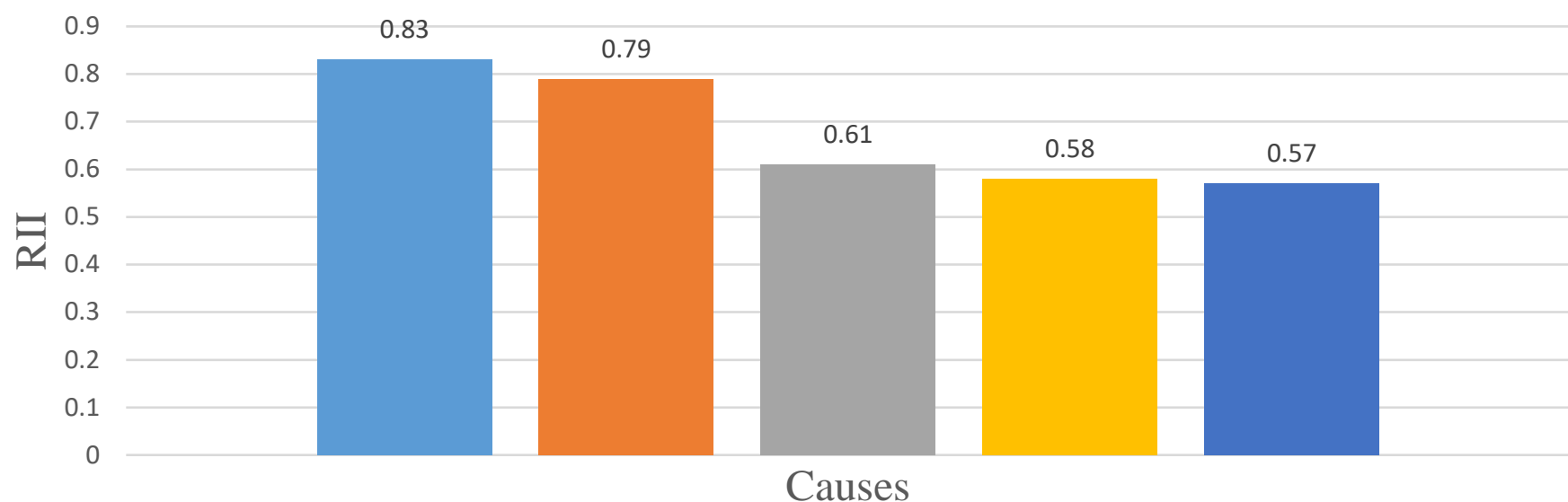

- Delay in payment (cash flow problem)

- Change of client's requirement

- Finance limitation to fund the project

- Oral change order (failure to give written instruction)

- Lack of awareness about construction

Figure 1: Client Related Causes of Claim

As one can see from the table 1 and figure 1 above delay in payment (cash flow problem) (with $\mathrm{RII}=0.83$ ) is the main client related cause of claim. This happen due to long line authority in the client's organization (bureaucracy), disagreeing on the valuation of work done, owners` financial management problem, delay of certification by owners, poor financial sources of owner and too many calls on the working capital of owners. Once again this affects the project by creating negative relationship among parties, affecting progress of the project, results in extension of time and suspension of progress of the work by subcontractors. Change of clients` requirement (with $\mathrm{RII}=0.79$ ) takes the second place. This is due to insufficient time allocation for briefing, absence of end users involvement, late exposition of requirements, and inexperience of client in construction. The third client related cause of claim is finance limitation to finance (fund) the project (with RII=0.61). This is mainly due to starting the project without having adequate money at hand, owners bossiness situation may be at rough condition and bankruptcy of the owners. The fourth and fifth client related cause of claim is oral change order or failure to give written instruction $(\mathrm{RII}=0.58)$ and lack of awareness about construction by clients ( $\mathrm{RII}=0.57$ ) respectively.

Table 2: RII and Rank of top 5 Contractor Related Causes of Claim (owners`and consultants ` perspective)

\begin{tabular}{|l|l|l|}
\hline Causes & RII & Rank \\
\hline Change of Market price(material cost and labour cost) & 0.86 & 1 \\
\hline Variation & 0.83 & 2 \\
\hline Poor communication with other parties & 0.78 & 3 \\
\hline Extension of time (delay in completion time) & 0.69 & 4 \\
\hline Lack of project management & 0.62 & 5 \\
\hline
\end{tabular}




\section{Top 5 Contractor related causes of claim}

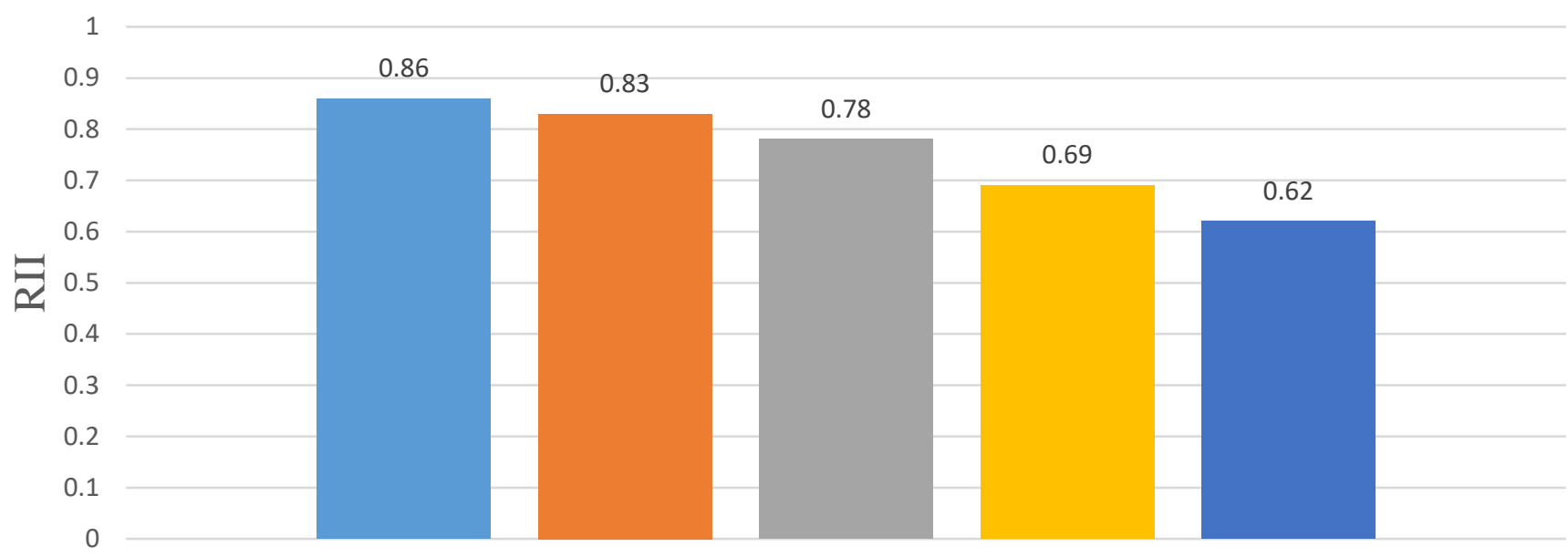

- Change of Market price(material and labour)

Causes

Poor communication with other parties

Variation

Extension of time (delay in completion time)

- Lack of project management

Figure 2: Contractor Related Causes of Claim

The result in the table 2 and figure 2 above shows change of market price (material cost and labour cost) (with $\mathrm{RII}=0.86$ ) is the main contractor related causes of claim. As the material price increase the contractor suspends the progress of the work until the market price settles which results delay in completion time of the project. Variation (with $\mathrm{RII}=0.83$ ) is the second contractor related cause of claim. This variation is due to Errors and omissions in design, improper specification of construction material, budget constraints, poor workmanship and change of schedule. Poor communication among the parties (with $\mathrm{RII}=0.78$ ) such as contractor, subcontractors and suppliers takes the third place as contractor related cause of claim. This is due to unreliable subcontractors, lack of communication, contractual problems, builder's defect and late update of revised information to subcontractors. Extension of time (delay in completion time) (with $\mathrm{RII}=0.69$ ) and Lack of project management (with $\mathrm{RII}=0.62$ ) takes the fourth and fifth place as contractor related causes of claim respectively.

Table 3: RII and Rank of top 5 Contract Document Related Causes of Claim

\begin{tabular}{|c|c|c|}
\hline Causes & RII & Rank \\
\hline Document management problem (non -computerization) & 0.67 & 3 \\
\hline Ambiguous (unclear) contract & 0.59 & 5 \\
\hline
\end{tabular}




\section{Top 5 Contract document Related causes of Claim}

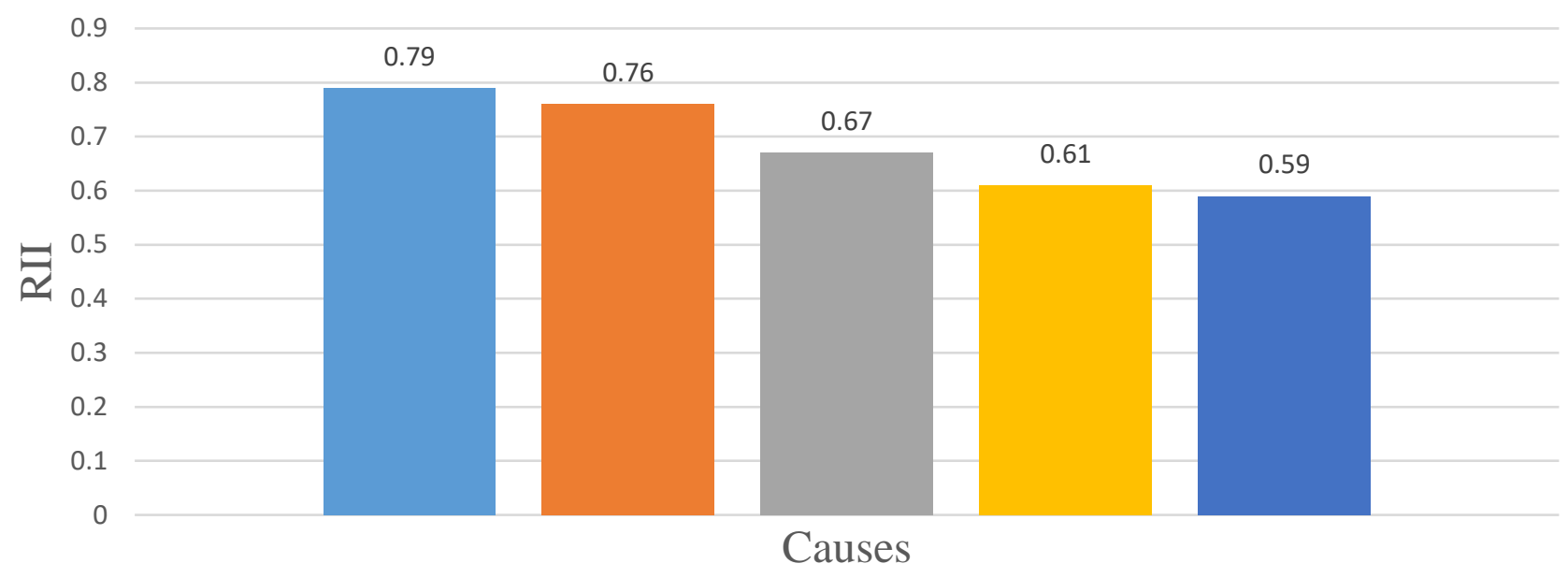

Incomplete design/ contract document

— Variation between executed work and original work

Document management problem (non-computerization) — Discrepancy between documents

- Ambiguous (unclear) contract

Figure 3: Contract Document Related Causes of Claim

The result in table 3 and figure 3 above shows that incomplete design/ contract document (with $\mathrm{RII}=0.79$ ) as primary document related cause of claim. Incomplete contract documents invariably lead to claims from contractors for extension of time and additional compensation when owners have tight budget or are reluctant to pay more for a project a dispute results [14]. Variation between executed work and original work (with $\mathrm{RII}=0.76$ ) takes the second place as contract document related cause of claim. This can be in the form of deduction from contract sum or addition to contract sum. This may result change in contract document and/or physical work which may lead to need for extension of time. Document management problem/ non-computerization (with RII=0.67) takes the third place as contract document related causes of claim. Good document management system (computerized document management system) helps as efficient way to keep financial records, automatically tallies amounts and provides reporting function, allow us to back up records, to easily control changes, reduce loss of data, correcting entries will be simple and reduce risk of corrupted data. The fourth and fifth document related cause of claim include discrepancy between contract documents (with $\mathrm{RII}=0.61$ ) and ambiguous (unclear) contract (with RII=0.59) respectively.

\section{CONCLUSION}

The result of the study and findings from literature review shows that the source for claim can be owner or owner's representative, contractor and contract document. According to respondents client related causes of claim includes 1) Delay in payment (cash flow problem), 2) change of client's requirement, 3) Finance limitation to fund the project, 4) Oral change order (failure to give written instruction) and 5) Lack of awareness about construction. Again contractor related causes of claim includes 1) Change of Market price (material cost and labour cost), 2) Variation, 3) Poor communication with other parties, 4) Extension of time (delay in completion time) and 5) Lack of project management. Finally contract document related causes of claim includes 1) Incomplete design (contract document), 2) Variation between executed work and original work, 3) Document management problem (non -computerization), 4) Discrepancy between documents and 5) Ambiguous (unclear) contract.

\section{ACKNOWLEDGMENT}

Thanks to everyone who contributed to this study especially Engineer Yohans Tadesse, Engineer kasaye G/meskel, Engineer Eyob Nigusse and Engineer Mekbib Mersha.

\section{REFERENCES}

[1] Vincent. and P-Smith and D,, Civil Engineering Claims, Oxford London., 1989.

[2] Wenxin shen, wenzhe tang, wenyang yu, colin f. Duffield, felix kin peng hui, yongping wei and jun fang, "causes of contractors' claims in international engineering-procurement-construction projects," journal of civil engineering and management, vol. 23, no. 6, p. $727-$ $739,2017$.

[3] Owenaze Joseph Ekhator, "investigating causes of disputes in building construction projects in nigeira," International Journal of Science, Environment and Technology, vol. 5, no. 5, p. 3516 - 3527, 2016.

[4] Jack Ramus, , Simon Birchall, and and Phil Griffith, Contract Practice for Surveyors, 4th edition,, Elsevier 1, Linacre House, Jordan Hil, 2006..

[5] M. A. Mohsin, "Claim Analysis of Construction Projects in Oman," International Journal on Advanced Science Engineering Information Technology, vol. 2, no. 2, pp. 73-78, 2012. 
[6] Abebe Dinku and Girmay Kahssay, "claims in international construction projects in ethiopia and case studies on selected projects," Journal of EEA, vol. 20, pp. 1-13, 2003.

[7] Bajere, P. A, Galadima, U. N. and Durodola, O. D. , "Covenant Journal of Research in the Built Environment (CJRBE)," Impact of Selected Project Characteristics on Construction Claims in Niger State, Nigeria, vol. 5, no. 1, pp. 11-31, 2017.

[8] FIDIC,Guide to the use of FIDIC 4, 1989.

[9] Abhishek Shah, Pg Scholar, , Dr. Rajiv Bhatt, H.O.D and Prof. J. J. Bhavsar, Pg Co-Ordinate, "Types and Causes of Construction Claims," International Journal of Engineering Research \& Technology (IJERT), vol. 3, no. 12, pp. 732-735, 2014.

[10] Eshetu Zenebe , Prof.Emer T.Quezon and Alemu Mosisa, "Contract claim Analysis on Building Construction Project in Addis Ababa: A case study at Yeka Sub City," International Journal Of Scientific \& Engineering Research, Volume 7, Issue 7 , July -2016, vol. 7, no. 7, pp. 1154-1160, 2016.
[11] Zewdu Tefera Worke and Environmental \& Engineering Contracts Lawyer, Construction Claims \& Disputes, Addis Ababa, Ethiopia.

[12] Dr. Wubishet Jekale, Claims in Local Construction Projects: Problems \& Prospects, by, Proceedings of Workshop on Claims in Construction Projects:Problems \& Prospects, Addis Ababa: Addis Ababa University, 2005.

[13] Sambasivan, M and Soon, Y. W, "Causes and effects of delays in Malaysian construction industry," international Journal of Project Management, vol. 25, no. 5, pp. 517-526, 2007.

[14] Bob Ken, "Project Managment and construction ckaims service," Revay and Associates limited, Toronto, 2010. 